\title{
High prevalence of bulimia nervosa in lupic patients
}

\author{
Lucia Miranda ${ }^{1}$, Ludmilla Costa ${ }^{1 *}$, Nadja Asano², Murilo Costa ${ }^{1}$ \\ From $1^{\text {st }}$ International Congress on Neurobiology and Clinical Psychopharmacology and European \\ Psychiatric Association Conference on Treatment Guidance \\ Thessaloniki, Greece. 19-22 November 2009
}

\section{Background}

Systemic erythematosus lupus is a chronic, inflammatory autoimmune disease and its common association with anxiety, depression and other psychiatric disorders is well known. Eating disorders in this particular population are not the center of attention. In this paper we describe the findings of our 9 months study with lupic patients at Hospital das Clinicas.

\section{Materials and methods}

We selected and interviewed 82 female patients (aged 18 to 40) suffering from lupus, using Mini International Neuropsychiatric Interview (MINI), as instrument of interview and diagnostic. Afterwards, patients diagnosed as bulimic were individually analysed.

\section{Results}

Twelve of the 82 patients had criteria for bulimia nervosa (14.63 per cent). Those patients had low self-steam, persistent preoccupation with weight gain related to medication. Many of them were also very preoccupied with other physical aspects, such as skin damage and hair loss.

\section{Conclusions}

An alarming high incidence of bulimia nervosa was found in this sample and this may indicate lupic patients are susceptible to eating disorders, considering their exposition to steroids and other medications related to weight gain. More studies are necessary in order to confirm such data.

'Departament of Neuropsychiatry, UFPE/Hospital das Clinicas, Recife, Pernambuco, Brazil

\section{Author details}

${ }^{1}$ Departament of Neuropsychiatry, UFPE/Hospital das Clinicas, Recife, Pernambuco, Brazil. 'Departament of Rheumatology, UFPE/Hospital das Clinicas, Recife, Pernambuco, Brazil.

Published: 22 April 2010

\section{References}

1. American Psychiatric Association: Diagnostic and statistical manual of mental disorders., 4.

2. Comprehensive Textbook of Psychiatry. , 72:1663-1672.

doi:10.1186/1744-859X-9-S1-S185

Cite this article as: Miranda et al.: High prevalence of bulimia nervosa in lupic patients. Annals of General Psychiatry 2010 9(Suppl 1):S185.
Submit your next manuscript to BioMed Central and take full advantage of:

- Convenient online submission

- Thorough peer review

- No space constraints or color figure charges

- Immediate publication on acceptance

- Inclusion in PubMed, CAS, Scopus and Google Scholar

- Research which is freely available for redistribution

Submit your manuscript at www.biomedcentral.com/submit
C Biomed Central 